\title{
Ent-kaurane Diterpenoids from Isodon rubescens var. lushanensis
}

\author{
Quan-Bin Han, ${ }^{a}$ Ma-Lin Li, ${ }^{b}$ Sheng-Hong LI, ${ }^{a}$ Yi-Kun Mou, ${ }^{b}$ Zhong-Wen LiN, ${ }^{a}$ and \\ Han-Dong SuN*,a \\ ${ }^{a}$ State Key Laboratory of Phytochemistry and Plant Resources in West China, Kunming Institute of Botany, Chinese \\ Academy of Sciences; Kunming 650204, P. R. China: and ${ }^{b}$ Yunnan Laboratory of Pharmacology for Natural Products, \\ Kunming Medical College; Kunming 650031, P. R. China. Received January 10, 2003; accepted February 25, 2003
}

Four new ent-kaurane diterpenoids lushanrubescensins F-I (1-4), together with 11 known ones, lasiodonin (5), oridonin (6), ponicidin (7), isodonoiol (8), isodonal (9), rabdosin B (10), rabdoternins A and B (11 and 12), enmenol (13), epinodosin (14), and inflexusin (15), were isolated from Isodon rubescens var. lushanensis, and the structures were elucidated by spectroscopic analysis. The inhibitory effect against the K562, Bcap37, BGC823, BIU87, CA, CNE, and Hela cell lines of compounds 3 and 5-10 were evaluated.

Key words Isodon rubescens var. lushanensis; Labiatae; ent-kauranoid; lushanrubescensin F; lushanrubescensin I; cytotoxity

Isodon rubescens (HELSM.) HARA (Labiatae), a perennial herb of the Isodon genus, which is a rich natural source of bioactive ent-kaurane diterpenoids, ${ }^{1)}$ is native to the Yellow River valley of China and used as an antitumor folk medicine in the treatment of esophageal and cardiac carcinoma in Henan Province, China. This medicinal plant was developed into a drug, which is in clinical use for its antibacterial and antiinflammatory activities. ${ }^{2}$ Many phytochemical studies focused on this plant and its varieties, leading to the isolation of more than 20 ent-kaurane diterpenoids. ${ }^{3)}$ From $I$.
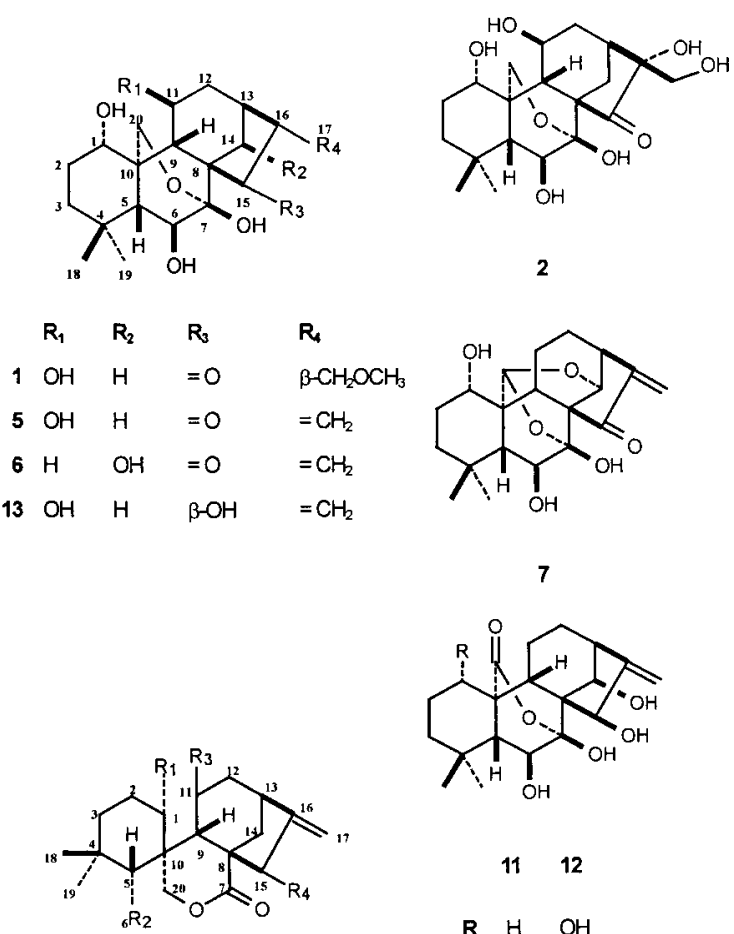

7
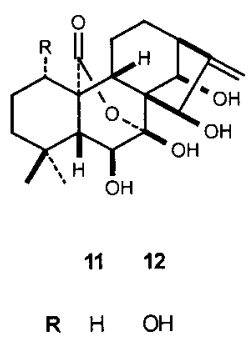

$\begin{array}{rllll} & \mathbf{R}_{1} & \mathbf{R}_{2} & \mathbf{R}_{3} & \mathbf{R}_{4} \\ 3 & \mathrm{OAC} & \mathrm{CH}_{2} \mathrm{OH} & \mathrm{H} & =0 \\ 4 & \mathrm{OH} & \mathrm{CHO} & \beta-\mathrm{OH} & \beta-O A C \\ 8 & \mathrm{OAC} & \mathrm{CH}_{2} \mathrm{OH} & \beta-\mathrm{OH} & =0 \\ 9 & \mathrm{OAC} & \mathrm{CHO} & \beta-\mathrm{OH} & =0 \\ 10 & \mathrm{OAC} & \mathrm{CH}_{2} \mathrm{OAC} & \beta-\mathrm{OH} & =0 \\ 15 & \mathrm{OAC} & \mathrm{CH}_{2} \mathrm{OAC} & \alpha-\mathrm{OAC} & \beta-O A C\end{array}$

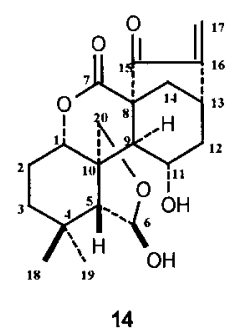

rubescens var. lushanensis collected in Lushan Prefecture of Henan Province, five 20-nonoxygenated ent-kaurane diterpenoids, lushanrubescensins $\mathrm{A}-\mathrm{E}$, were reported previously, ${ }^{4-7)}$ differing greatly from 7,20-epoxy or 6,7-seco ent-kauranoids isolated from $I$. rubescens and its varieties collected in other prefectures. In our reinvestigation of the constituents of I. rubescens var. lushanensis, 15 ent-kaurane diterpenoids including four new compounds $(\mathbf{1}-\mathbf{4})$ were isolated, none of which was a 20-nonoxygenated ent-kaurane diterpenoid. Compounds $\mathbf{3}$ and 5-10 were evaluated for their inhibitory effect against K562 and Bcap37 (human breast cancer cell lines), CA (human liver cancer cell line), CNE (human nasopharyngeal cancer cell line), BIU87 (human cystic cancer cell line), BGC823 (human stomach cancer cell line), and Hela cell lines. Herein, we report the isolation and structure elucidation as well as the cytotoxity evaluation results.

\section{Results and Discussion}

Compound 1, obtained as colorless needles, showed the molecular ion peak at $\mathrm{m} / \mathrm{z} 396.2165$ in its high resolution electron impact (HR-EI)-MS, corresponding to the molecular formula $\mathrm{C}_{21} \mathrm{H}_{32} \mathrm{O}_{7}$. This was corroborated by the ${ }^{13} \mathrm{C}$ - and distortionless enhancement by polarization transfer (DEPT)NMR spectra, which exhibited signals for all 20 carbons of the diterpene skeleton in addition to a methoxyl group.

On the basis of the characteristic signals of three methines $\left(\delta_{\mathrm{C}} 61.5,58.3,29.8\right.$ due to $\mathrm{C}-5,9$, and 13$)$, three quaternary carbons $\left(\delta_{\mathrm{C}} 61.1,42.5,34.2\right.$ assignable to $\mathrm{C}-8,10$, and 4$)$, two methyls ( $\delta_{\mathrm{C}} 32.9$ and 22.3 attributable to $\mathrm{C}-18$ and 19 ), an oxygenated methylene $\left(\delta_{\mathrm{C}} 64.6\right.$, assigned as $\left.\mathrm{C}-20\right)$, and a hemiketal quaternary carbon $\left(\delta_{\mathrm{C}} 95.5, \mathrm{C}-7\right)$, along with the structures of the compounds isolated previously from this plant, we assumed that compound 1 should be a 7,20-epoxyent-kaurane diterpenoid similar to lasiodonin (5), ${ }^{8,9)}$ which was also isolated as one of the major constituents. Comparison of the NMR data between the two compounds confirmed the above deduction, and indicated that compound $\mathbf{1}$ was identical to $\mathbf{5}$ except for $\mathrm{C}-16$ and $\mathrm{C}-17$. The exomethylene group at C-16 of 5 was replaced by a methine $\left(\delta_{\mathrm{C}} 58.4, \mathrm{C}-16\right.$; $\left.\delta_{\mathrm{H}} 2.95, \mathrm{H}-16\right)$ and an oxygenated methylene $\left(\delta_{\mathrm{C}} 68.9, \mathrm{C}-17\right.$; $\delta_{\mathrm{H}} 3.75$ and $\left.3.62, \mathrm{H}_{2}-17\right)$ in 1 . Furthermore, the additional methoxyl was located on this oxygenated methylene carbon by the heteronuclear multiple bond connectivity (HMBC) 
correlation (Fig. 1) between the methoxyl protons $\left(\delta_{\mathrm{H}} 3.19\right)$ with this carbon. Therefore, compound $\mathbf{1}$ was determined to be $16(S)-1 \alpha, 6 \beta, 7 \beta, 11 \beta$-tetrahydroxy-17-methoxy-7 $\alpha, 20$ epoxy-ent-kaur-15-one by the nuclear Overhauser effect (NOE) (Fig. 1) between H-17 with $\mathrm{H}-12 \beta\left(\delta_{\mathrm{H}} 1.28\right)$ in the rotating frame Overhauser enhancement spectroscopy (ROESY) spectrum of $\mathbf{1}$, and called lushanrubescensin F. All the NMR data of $\mathbf{1}$ were unambiguously assigned based on the two dimensional (2D)-NMR spectra including ${ }^{1} \mathrm{H}-{ }^{1} \mathrm{H}$ correlation spectroscopy (COSY), ${ }^{1} \mathrm{H}$-detected heteronuclear multiple quantum coherence (HMQC), HMBC, and ROESY.

Compound 2, obtained as a white amorphous powder, exhibited a quasimolecular ion peak at $m / z 399.2035$ in its positive HR-FAB-MS in agreement with the molecular formula

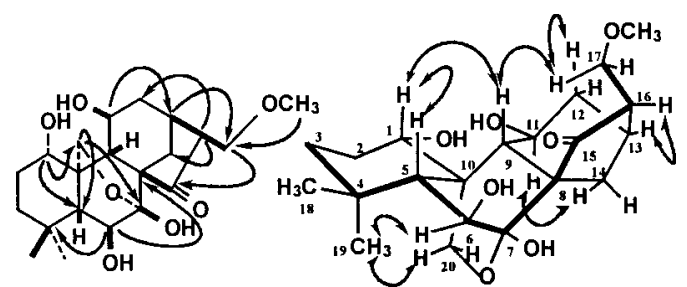

Fig. 1. Key HMBC (from $\mathrm{H}$ to $\mathrm{C}$ ) and ROESY Correlations of $\mathbf{1}$
$\mathrm{C}_{20} \mathrm{H}_{31} \mathrm{O}_{8}$. The analyses of the ${ }^{1} \mathrm{H}-$ and ${ }^{13} \mathrm{C}-\mathrm{NMR}$ data of $\mathbf{2}$ indicated that compound 2 was also a 7,20-epoxy-ent-kauranoid. On the basis of the comparison of the ${ }^{13} \mathrm{C}-\mathrm{NMR}$ spectrum of $\mathbf{2}$ with that of $\mathbf{1}$ (Table 1), it was revealed that these two compounds were very similar except for two more hydroxyl groups and one less methoxyl group in $\mathbf{2}$ than in $\mathbf{1}$. One of these hydroxyl groups was assigned to $\mathrm{C}-17$ by the HMBC interactions of $\mathrm{H}_{2}-17\left(\delta_{\mathrm{H}} 4.46\right)$ with $\mathrm{C}-15\left(\delta_{\mathrm{C}} 223.3\right)$ and $\mathrm{C}-13\left(\delta_{\mathrm{C}} 37.8\right)$. The other hydroxyl group was located at $\mathrm{C}-16$ by the $\mathrm{HMBC}$ correlations arising from $\mathrm{H}_{2}-17$ and $\mathrm{H}_{2}-$ $14\left(\delta_{\mathrm{H}} 3.51\right.$ and 2.50$)$ with C-16 $\left(\delta_{\mathrm{C}} 82.7\right)$. Furthermore, the relative configuration of $\mathrm{C}-16$ was determined to be $R$ by the NOE between $\mathrm{H}_{2}-17$ with $\mathrm{H}-12 \beta\left(\delta_{\mathrm{H}} 2.42\right)$. Consequently, compound 2 was elucidated to be $16(R)-1 \alpha, 6 \beta, 7 \beta, 11 \beta$, 16,17-hexahydroxy-7 $\alpha, 20$-epoxy-ent-kaur-15-one, and called lushanrubescensin G.

Compound 3, obtained as colorless needles, showed an $[\mathrm{M}+\mathrm{H}]^{+}$ion peak at $m / z 391.2129$ in its positive HR-FABMS, consistent with the molecular formula $\mathrm{C}_{22} \mathrm{H}_{31} \mathrm{O}_{6}$ which was confirmed by its ${ }^{13} \mathrm{C}$-NMR spectrum presenting signals for all 22 carbons of the molecular formula including two carbons of an acetoxyl group. On the basis of the characteristic lactone carbonyl signal at $\delta_{\mathrm{C}} 170.9$ (s) due to C-7 and no-

Table 1. ${ }^{1} \mathrm{H}$ - and ${ }^{13} \mathrm{C}-\mathrm{NMR}$ Data of Compounds $\mathbf{1}-\mathbf{4}\left(500\right.$ and $125 \mathrm{MHz}$, in $\mathrm{C}_{5} \mathrm{D}_{5} \mathrm{~N}, \delta$ in ppm, $J$ in $\left.\mathrm{Hz}\right)$

\begin{tabular}{|c|c|c|c|c|c|c|c|c|}
\hline & \multicolumn{2}{|l|}{1} & \multicolumn{2}{|l|}{2} & \multicolumn{2}{|l|}{3} & \multicolumn{2}{|l|}{4} \\
\hline & $\delta_{\mathrm{H}}$ & $\delta_{\mathrm{C}}$ & $\delta_{\mathrm{H}}$ & $\delta_{\mathrm{C}}$ & $\delta_{\mathrm{H}}$ & $\delta_{\mathrm{C}}$ & $\delta_{\mathrm{H}}$ & $\delta_{\mathrm{C}}$ \\
\hline $1 \beta$ & $4.16^{a)}$ & $73.2 \mathrm{~d}$ & $4.18 \mathrm{~m}$ & $73.4 \mathrm{~d}$ & $5.02 \mathrm{dd}, 3.0,10.6$ & $77.0 \mathrm{~d}$ & $5.69 \mathrm{dd}, 2.8,10.0$ & $76.2 \mathrm{~d}$ \\
\hline $2 \alpha$ & $2.80 \mathrm{~m}$ & $28.3 \mathrm{t}$ & $2.82 \mathrm{~m}$ & $28.5 \mathrm{t}$ & $\left.2.00-1.80^{a}\right)$ & $24.3 \mathrm{t}$ & $2.05 \mathrm{~m}$ & $24.4 \mathrm{t}$ \\
\hline $2 \beta$ & $1.84 \mathrm{~m}$ & & $1.86 \mathrm{~m}$ & & $2.00-1.80^{a)}$ & & $1.99 \mathrm{~m}$ & \\
\hline $3 \alpha$ & 1.43 br d, 12.4 & $39.8 \mathrm{t}$ & $1.42 \mathrm{~m}$ & $39.9 \mathrm{t}$ & $1.33-1.40^{a)}$ & $39.9 \mathrm{t}$ & $1.33 \mathrm{~m}$ & $40.3 \mathrm{t}$ \\
\hline $3 \beta$ & 1.32 brt, 12.4 & & $1.31 \mathrm{~m}$ & & $1.33-1.40^{a)}$ & & $1.45 \mathrm{~m}$ & \\
\hline 4 & & $34.2 \mathrm{~s}$ & & $34.4 \mathrm{~s}$ & & $33.8 \mathrm{~s}$ & & $34.4 \mathrm{~s}$ \\
\hline $5 \beta$ & $1.50 \mathrm{~d}, 4.8$ & $61.5 \mathrm{~d}$ & $1.53 \mathrm{~d}, 5.6$ & $61.2 \mathrm{~d}$ & 1.72 br s & $53.5 \mathrm{~d}$ & $4.41 \mathrm{~s}$ & $61.5 \mathrm{~d}$ \\
\hline $6 \alpha$ & $4.16^{a)}$ & $74.3 \mathrm{~d}$ & $4.26 \mathrm{dd}, 5.6,10.0$ & $74.7 \mathrm{~d}$ & $3.82,2 \mathrm{H}$, br s & $58.8 \mathrm{t}$ & 10.43 br s & $205.1 \mathrm{~d}$ \\
\hline \multicolumn{9}{|c|}{$1.20 \mathrm{cu}, 0.0,10.0$} \\
\hline 7 & & $95.5 \mathrm{~s}$ & & $95.8 \mathrm{~s}$ & & $170.9 \mathrm{~s}$ & & $175.4 \mathrm{~s}$ \\
\hline 8 & & $61.1 \mathrm{~s}$ & & $61.2 \mathrm{~s}$ & & $58.6 \mathrm{~s}$ & & $53.3 \mathrm{~s}$ \\
\hline $9 \beta$ & $1.86^{a)}$ & $58.3 \mathrm{~d}$ & $2.04 \mathrm{~d}, 11.2$ & $58.3 \mathrm{~d}$ & $3.20 \mathrm{dd}, 4.0,13.0$ & $42.2 \mathrm{~d}$ & $3.19 \mathrm{~d}, 10.0$ & $42.6 \mathrm{~d}$ \\
\hline 10 & & $42.5 \mathrm{~s}$ & & $42.7 \mathrm{~s}$ & & $44.3 \mathrm{~s}$ & & $43.8 \mathrm{~s}$ \\
\hline $11 \alpha$ & $4.79 \mathrm{~m}$ & $63.3 \mathrm{~d}$ & $4.88 \mathrm{~m}$ & $63.5 \mathrm{~d}$ & $1.80^{a)}$ & $17.8 \mathrm{t}$ & $4.38 \mathrm{~m}$ & $65.5 \mathrm{~d}$ \\
\hline $11 \beta$ & & & & & $1.50 \mathrm{~m}$ & & & \\
\hline $12 \alpha$ & 1.75 br t, 12.8 & $30.4 \mathrm{t}$ & $2.81 \mathrm{~m}$ & $32.3 \mathrm{t}$ & $1.30^{a)}$ & $30.1 \mathrm{t}$ & $2.59 \mathrm{~m}$ & $44.7 \mathrm{t}$ \\
\hline $12 \beta$ & $1.22^{a)}$ & & $2.42 \mathrm{~m}$ & & $1.33^{a)}$ & & 1.69 br t, 10.0 & \\
\hline $13 \alpha$ & $2.50 \mathrm{brs}$ & $29.8 \mathrm{~d}$ & $3.03 \mathrm{~m}$ & $37.8 \mathrm{~d}$ & $2.91 \mathrm{~m}$ & $35.2 \mathrm{~d}$ & $2.69 \mathrm{~m}$ & $36.0 \mathrm{t}$ \\
\hline $14 \alpha$ & $2.44 \mathrm{~m}$ & $29.2 \mathrm{t}$ & $2.50 \mathrm{brd}, 12.4$ & $26.5 \mathrm{t}$ & 2.04 br d, 12.0 & $29.2 \mathrm{t}$ & 1.85 br d, 12.0 & $30.6 \mathrm{t}$ \\
\hline $14 \beta$ & $1.89^{a)}$ & & $3.51 \mathrm{dd}, 2.4,12.4$ & & $2.58 \mathrm{dd}, 4.8,12.0$ & & $2.28 \mathrm{dd}, 5.0,12.0$ & \\
\hline $15 \alpha$ & & $224.3 \mathrm{~s}$ & & $223.3 \mathrm{~s}$ & & $202.5 \mathrm{~s}$ & $4.92 \mathrm{br} \mathrm{s}$ & $83.5 \mathrm{~d}$ \\
\hline 16 & $2.95 \mathrm{~m}$ & $58.4 \mathrm{~d}$ & & $82.7 \mathrm{~s}$ & & $151.3 \mathrm{~s}$ & & $159.7 \mathrm{~s}$ \\
\hline \multirow[t]{2}{*}{17} & $3.75 \mathrm{dd}, 4.0,10.0$ & $68.9 \mathrm{t}$ & $4.462 \mathrm{H}, \mathrm{s}$ & $63.7 \mathrm{t}$ & $5.96 \mathrm{~s}$ & $118.3 \mathrm{t}$ & $5.45 \mathrm{~s}$ & $109.6 \mathrm{t}$ \\
\hline & $3.62 \mathrm{dd}, 8.0,10.0$ & & & & $5.34 \mathrm{~s}$ & & $5.20 \mathrm{~s}$ & \\
\hline 18 & $1.173 \mathrm{H}, \mathrm{s}$ & $32.9 \mathrm{q}$ & $1.193 \mathrm{H}, \mathrm{s}$ & $33.1 \mathrm{q}$ & $0.993 \mathrm{H}, \mathrm{s}$ & $33.5 \mathrm{q}$ & $0.933 \mathrm{H}, \mathrm{s}$ & $33.3 \mathrm{q}$ \\
\hline 19 & $1.073 \mathrm{H}, \mathrm{s}$ & $22.3 \mathrm{q}$ & $1.103 \mathrm{H}, \mathrm{s}$ & $22.5 \mathrm{q}$ & $0.783 \mathrm{H}, \mathrm{s}$ & $23.5 \mathrm{q}$ & $1.053 \mathrm{H}, \mathrm{s}$ & $24.1 \mathrm{q}$ \\
\hline \multirow[t]{2}{*}{20} & $4.64 \mathrm{~d}, 10.8$ & $64.6 \mathrm{t}$ & $4.75 \mathrm{~d}, 10.0$ & $64.7 \mathrm{t}$ & $5.12 \mathrm{~d}, 12.0$ & $68.9 \mathrm{t}$ & $5.51 \mathrm{~d}, 12.0$ & $67.1 \mathrm{t}$ \\
\hline & $4.39 \mathrm{~d}, 10.8$ & & $4.45 \mathrm{~d}, 10.0$ & & $4.84 \mathrm{~d}, 12.0$ & & $5.26 \mathrm{~d}, 12.0$ & \\
\hline $1-\mathrm{OH}$ & $6.48 \mathrm{~s}$ & & $6.69 \mathrm{~s}$ & & & & & \\
\hline $6-\mathrm{OH}$ & $6.33 \mathrm{~d}, 11.0$ & & $6.59 \mathrm{~d}, 10.0$ & & & & & \\
\hline 7-OH & $8.82 \mathrm{~s}$ & & & & & & & \\
\hline 11-OH & $6.48 \mathrm{~s}$ & & & & & & & \\
\hline $1-\mathrm{OAc}$ & & & & & $2.16 \mathrm{~s}$ & $\begin{array}{r}170.2 \mathrm{~s} \\
21.4 \mathrm{q}\end{array}$ & & \\
\hline 15-OAc & & & & & & & $2.18 \mathrm{~s}$ & $\begin{array}{r}170.4 \mathrm{~s} \\
21.4 \mathrm{~g}\end{array}$ \\
\hline
\end{tabular}


ticeable oxygenated methylene signals $\left[\delta_{\mathrm{C}} 68.9(\mathrm{t}), \mathrm{C}-20 ; \delta_{\mathrm{H}}\right.$ 5.12 and $\left.4.84(\mathrm{~d}, J=12.0 \mathrm{~Hz}), \mathrm{H}_{2}-20\right]$, compound 3 was inferred to be a 6,7-seco-7,20-olide ent-kauranoid, similar to isodonoiol $(\mathbf{8}){ }^{10,11)}$ a known analogue also isolated in this study. Through comparison of the 1D-NMR data of two compounds ( $\mathbf{3}$ and $\mathbf{8}$ ), it was indicated that compound $\mathbf{3}$ was 11dehydroxy-isodonoiol, which was confirmed by the HMBC and ROESY correlations of $\mathbf{3}$ (Fig. 2). Thus compound $\mathbf{3}$ was finally established to be 6-hyroxy- $1 \alpha$-acetoxy-6,7-seco-7,20olide-ent-kaur-16-en-15-one, and called lushanrubescensin H.

Compound 4, an amorphous powder, was also indicated to be a 6,7-seco-7,20-olide-ent-kaurane diterpenoid by the analyses of its 1D-NMR spectra, with the molecular formula $\mathrm{C}_{22} \mathrm{H}_{30} \mathrm{O}_{7}$ determined by the HR-EI-MS (Found 406.1976, Calcd 406.1992). By the comparison of the ${ }^{13} \mathrm{C}-\mathrm{NMR}$ data of 4 with those of isodonal (9), ${ }^{10,11)}$ a known 6,7-seco-7,20olide-ent-kauranoid obtained at the same time, it was revealed that 4 differed from 9 mainly at C-15. An acetoxyl group was confirmed to be linked with $\mathrm{C}-15$ of 4 by the HMBC correlations of H-15 $\left(\delta_{\mathrm{H}} 4.92\right)$ with the acetoxyl carbonyl carbon $\left(\delta_{\mathrm{C}} 170.4\right), \mathrm{C}-9\left(\delta_{\mathrm{C}} 42.6\right)$, and C-17 $\left(\delta_{\mathrm{C}} 109.6\right)$, and $\mathrm{H}_{2}-17\left(\delta_{\mathrm{H}} 5.45\right.$ and 5.20) with C-15 $\left(\delta_{\mathrm{C}} 83.5\right)$. This acetoxyl group was further indicated to be $\beta$-orientated by the ROESY correlation between H-15 with $\mathrm{H}-14 \beta\left(\delta_{\mathrm{H}} 2.28\right)$. Thus compound 4 was assigned to be $1 \alpha$-hydroxy- $15 \beta$-acetoxy-6-oxo-6,7-seco-7,20-olide-ent-kaur-16-ene, and called lushanrubescensin I.

The structures of known compounds 5-15 were established to be lasiodonin $(\mathbf{5}),{ }^{8,9)}$ isodonoiol $(\mathbf{8}),{ }^{10,11)}$ isodonal $(\mathbf{9}),{ }^{10,12)}$ rabdoternins A and B $\left(\mathbf{1 1}\right.$ and 12) ${ }^{13)}$ oridonin $(\mathbf{6}),{ }^{14)}$ ponicidin (7), ${ }^{15)}$ rabdosin B (10), ${ }^{16)}$ enmenol (13), ${ }^{17)}$ epinodosin (14) ${ }^{18)}$ and inflexusin (15), ${ }^{19)}$ by comparison of their spectral data with literature values. The reinvestigation results were very different from those reported in the literature, ${ }^{4)}$ in which five 20-nonoxygenated ent-kauranoids had been reported from I. rubescens var. lushanensis collected in Lushan Prefecture of Henan Province, while the 15 ent-kauranoids obtained in our study from the same plant

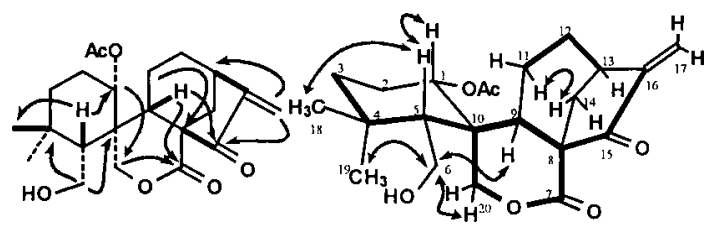

Fig. 2. Key HMBC (from $\mathrm{H}$ to $\mathrm{C}$ ) and ROESY Correlations of $\mathbf{3}$ collected in the same prefecture were 20-oxygenated. The different results showed that the structural types of secondary metabolites change with the different ecological environment or habitat of I. rubescens and its varieties.

Considering the application of this medical plant in drug production in China, we think it is necessary to perform further chemical and phytotaxological studies on this plant.

Compounds $\mathbf{3}$ and 5-10 were tested for their inhibitory effects against K562, Bcap37, BGC823, BIU87, CA, CNE, and Hela cell lines, with cisplatin as the positive reference substance. The results are presented in Table 2. Compounds 3, 7 and 9 showed abilities to inhibit K562 cells camparable to that of cisplatin, while compounds $\mathbf{6}$ and $\mathbf{7}$ exhibited significant inhibitory effects against the CA cell line. But none of these compounds displayed an obvious inhibitory effect against Bcap37, BGC823, BIU87, CNE, and Hela cell lines.

\section{Experimental}

General Procedures Melting points were measured on an XRC-1 micro melting point apparatus and are uncorrected. Optical rotations were measured on a JASCO DIP-370 digital polarimeter. UV absorptions were obtained on a Shimadzu UV-2401PC UV-VIS recording spectrophotometer. IR spectra were determined on a Bio-Rad FtS-135 spectrophotometer with $\mathrm{KBr}$ pellets. MS were recorded on a VGAuto Spec-3000 spectrometer. 1D- and 2D-NMR spectra were run on Brucker AM-400 and DRX-50 instruments with tetramethylsilane (TMS) as an internal standard.

Plant Material The leaves of I. rubescens var. lushanensis were collected in Lushan Prefecture of Hennan Province in August 2000 and airdried. The identity of the plant material was verified by Prof. Zhong-Wen Lin, and a voucher specimen (KIB-2000-10 Lin) is deposited in the Herbarium of the Department of Taxonomy, Kunming Institute of Botany, Chinese Academy of Science.

Extraction and Isolation The dried and powdered leaves $(8.0 \mathrm{~kg})$ were extracted with $70 \% \mathrm{Me}_{2} \mathrm{CO}$ and filtered. The filtrate was concentrated and partitioned successively between petroleum ether and water and then EtOAc and water. The EtOAc extract ( $370 \mathrm{~g})$ was applied to column chromatography over a silica gel $(100-200 \mathrm{mesh}, 3.5 \mathrm{~kg})$ column eluted with a system of $\mathrm{CHCl}_{3}-\mathrm{Me}_{2} \mathrm{CO}(10: 0,9: 1,8: 2,7: 3,6: 4,5: 5)$. The $\mathrm{CHCl}_{3}$ fraction was further chromatographed repeatedly over silica gel to afford $\mathbf{1 0}(80 \mathrm{mg})$ and $15(10 \mathrm{mg})$. Then repeated chromatography of the $\mathrm{CHCl}_{3}-\mathrm{Me}_{2} \mathrm{CO}(9: 1)$ fraction over silica gel yielded $14(3.4 \mathrm{~g}), 3(8.0 \mathrm{mg}), 4(16.0 \mathrm{mg}), 5$ ( $800 \mathrm{mg}), \mathbf{6}(3.0 \mathrm{~g})$, and 7 (120 mg). Compounds 8 (20 mg), 9 (40 mg), 11 $(5.0 \mathrm{mg})$, and $12(2.0 \mathrm{mg})$ were isolated from the $\mathrm{CHCl}_{3}-\mathrm{Me}_{2} \mathrm{CO}(8: 2)$ fraction in the same way. The $\mathrm{CHCl}_{3}-\mathrm{Me}_{2} \mathrm{CO}(7: 3)$ fraction was similarly chromatographed on silica gel and refined with preparative TLC to yield compounds $1(6.0 \mathrm{mg}), \mathbf{2}(2.0 \mathrm{mg})$, and $\mathbf{1 3}(20.0 \mathrm{mg})$.

Compound 1: Colorless needles, mp 202-203 ${ }^{\circ} \mathrm{C}$. $[\alpha]_{\mathrm{D}}^{20}-77.3^{\circ}(c=0.11$, acetone). UV $\lambda_{\max }(\mathrm{MeOH}) \mathrm{nm}(\log \varepsilon): 210(2.91)$. IR $(\mathrm{KBr}) v_{\max } \mathrm{cm}^{-1}$ : 3408, 2941, 2907, 1717, 1635, 1456, 1392, 1194, 1170, 1089, 1055. ${ }^{1} \mathrm{H}-$ and ${ }^{13} \mathrm{C}$-NMR $\left(\mathrm{C}_{5} \mathrm{D}_{5} \mathrm{~N}\right)$ data: see Table 1. EI-MS $m / z(\%): 396[\mathrm{M}]^{+}(6), 378(8)$, 364 (100), 346 (7), 328 (5), 300 (4). HR-EI-MS m/z: 396.2165 (Calcd for $\left.\mathrm{C}_{21} \mathrm{H}_{32} \mathrm{O}_{7}, 396.2148\right)$.

Compound 2: White amorphous powder, $[\alpha]_{\mathrm{D}}^{20}-40.2^{\circ}(c=0.06$, acetone).

Table 2. Inhibitory Effects of Compounds $\mathbf{3}$ and 5-10 against Various Cell Lines

\begin{tabular}{|c|c|c|c|c|c|c|c|}
\hline \multirow{2}{*}{ Compound } & \multicolumn{7}{|c|}{$\mathrm{IC}_{50}(\mu \mathrm{g} / \mathrm{ml})$ for cell lines } \\
\hline & K562 & Bcap37 & BGC 823 & BIU87 & $\mathrm{CA}$ & $\mathrm{CNE}$ & Hela \\
\hline 3 & 3.56 & 13.42 & 8.91 & ND & 8.25 & ND & $>100$ \\
\hline 5 & 5.35 & 112.53 & a) & a) & a) & a) & a) \\
\hline 6 & 4.37 & 8.32 & ND & 55.91 & 0.06 & 16.50 & 28.67 \\
\hline 7 & 2.26 & 6.76 & 55.17 & 13.26 & 0.06 & 13.26 & 11.31 \\
\hline 8 & 10.15 & 101.32 & a) & a) & a) & a) & a) \\
\hline 9 & 2.29 & 28.64 & 79.87 & ND & 9.04 & ND & $>100$ \\
\hline 10 & 4.61 & 15.84 & 10.93 & ND & $>100$ & ND & $>100$ \\
\hline Cisplatin & 3.84 & 1.54 & 2.54 & 4.34 & 0.88 & 6.54 & 3.60 \\
\hline
\end{tabular}

a) Not tested. ND: not determined. 
UV $\lambda_{\max }(\mathrm{MeOH}) \mathrm{nm}(\log \varepsilon): 212$ (3.26). IR $(\mathrm{KBr}) v_{\max } \mathrm{cm}^{-1}: 3428,2925$, $1771,1716,1682,1651,1621,1558,1540,1520,1457,1397,1374 .{ }^{1} \mathrm{H}-$ and ${ }^{13} \mathrm{C}-\mathrm{NMR}\left(\mathrm{C}_{5} \mathrm{D}_{5} \mathrm{~N}\right)$ data: see Table 1. Positive FAB-MS $m / z$ : $399[\mathrm{M}+1]^{+}$. Positive HR-FAB-MS m/z: 399.2035 (Calcd for $\mathrm{C}_{20} \mathrm{H}_{31} \mathrm{O}_{8}, 399.2019$ ).

Compound 3: Colorless needles, $\mathrm{mp} 201-202^{\circ} \mathrm{C}$. $[\alpha]_{\mathrm{D}}^{20}+31.8^{\circ}(c=0.32$, acetone). UV $\lambda_{\max }(\mathrm{MeOH}) \mathrm{nm}(\log \varepsilon): 229$ (3.81). IR (KBr) $v_{\max } \mathrm{cm}^{-1}$ : 3450, 1745, 1714, 1672, 1450, 1333. ${ }^{1} \mathrm{H}-$ and ${ }^{13} \mathrm{C}-\mathrm{NMR}\left(\mathrm{C}_{5} \mathrm{D}_{5} \mathrm{~N}\right)$ data: see Table 1. Positive FAB-MS $m / z: 391[\mathrm{M}+1]^{+}$. Positive HR-FAB-MS $m / z$ : 391.2129 (Calcd for $\mathrm{C}_{22} \mathrm{H}_{31} \mathrm{O}_{6}, 391.2121$ ).

Compound 4: Amorphous powder, $[\alpha]_{\mathrm{D}}^{20}+45.2^{\circ}(c=1.99, \mathrm{MeOH})$. UV $\lambda_{\text {max }}(\mathrm{MeOH}) \mathrm{nm}(\log \varepsilon): 212$ (3.22). IR (KBr) $v_{\max } \mathrm{cm}^{-1}: 3444,2950,2873$, $1735,1710,1464,1410,1371,1296,1239,1125$. ${ }^{1} \mathrm{H}-$ and ${ }^{13} \mathrm{C}-\mathrm{NMR}$ $\left(\mathrm{C}_{5} \mathrm{D}_{5} \mathrm{~N}\right)$ data: see Table 1. EI-MS $m / z(\%): 404[\mathrm{M}-2]^{+}(2), 386(20), 358$ (4), 344 (6), 326 (6), 298 (10), 148 (40), 107 (100). HR-EI-MS m/z: 406.1976 (Calcd for $\mathrm{C}_{22} \mathrm{H}_{30} \mathrm{O}_{7}, 406.1992$ ).

Cytotoxicity against Human Tumor K562 Cells A cytotoxicity assay against the K562 cell line was performed using the improved MTT [3-(4,5-dimethylthiazol-2-yl)-2,5-diphenyl-tetrazolium bromide] colorimetric method. ${ }^{20)} \mathrm{K} 562$ cells at the log phase of their growth cycle $\left(4 \times 10^{4}\right.$ cells $/ \mathrm{ml})$ were added to each well $(90 \mu \mathrm{l} / \mathrm{well})$, then treated in five replicates at various concentrations of the samples $(100,10,1,0.1,0.01 \mu \mathrm{g} / \mathrm{ml})$, and incubated for $48 \mathrm{~h}$ at $37{ }^{\circ} \mathrm{C}$ in a humidified atmosphere of $5 \% \mathrm{CO}_{2}$. Thereafter each well was treated with MTT solution $10 \mu \mathrm{l}(5 \mathrm{mg} / \mathrm{ml})$ and further incubated for $4 \mathrm{~h}$. Then, a three-system solution of $10 \%$ SDS- $5 \%$ isobutanol- $-0.012 \mathrm{ml} / 1 \mathrm{HCl}$ was added to each well $(100 \mu \mathrm{l} /$ well $)$. The OD of each well was recorded at room temperature $12 \mathrm{~h}$ later on an ELISA reader (Bioteck EL-340, U.S.A.) at two wavelengths $(570,630 \mathrm{~nm})$. In these experiments, the negative reference agents were isochoric normal saline, $1 \%$ DMSO, or $0.1 \%$ DMSO, and cisplatin was used as the positive reference substance at three concentrations $(10,1$, and $0.1 \mu \mathrm{g} / \mathrm{ml})$.

Cytotoxicity against Bcap37, BGC823, BIU87, CA, CNE, and Hela Cell Lines Exponentially growing Bcap37, BGC823, BIU87, CA, CNE, or Hela cells were dissociated with $0.25 \%$ trypsin in D-Hanks buffer. They were formed into a single-well suspension of density $\left(4 \times 10^{4} \mathrm{cells} / \mathrm{ml}\right)$ by RPMI-1640 containing 10\% heat-inactivated bovine serum. Ninety microliters of the cell suspension were added to each well of the 96-well microplate. Cultures were preincubated for $24 \mathrm{~h}$ in a $5 \% \mathrm{CO}_{2}$ atmosphere and $100 \%$ humidity incubator. After that, $10 \mu \mathrm{l}$ of the test solution was added to each well of the 96-well microplate (each concentration was tested in quadruplicate wells). Then cells were incubated at $37^{\circ} \mathrm{C}$ in a $5 \% \mathrm{CO}_{2}$ atmosphere for an additional $72 \mathrm{~h}$. At the end of exposure, the cells were fixed by the addition of $50 \mu$ of cold $50 \%$ trichloroacetic acid (TCA) at $4{ }^{\circ} \mathrm{C}$ for $1 \mathrm{~h}$. After fixation, cultures were washed five times with tap water. When the plates were air-dried, TCA-fixed cells in each well were stained with a $0.4 \%$ $50 \mu 1$ sulforhodamin B (SRB) solution in $1 \%$ acetic acid for $30 \mathrm{~min}$. At the end of the staining period, SRB was removed and cultures were rinsed four times with $1 \%$ acetic acid to remove unbound dye. After being rinsed, the cultures were air-dried until no standing moisture was visible. Then $10 \mathrm{~mm}$ unbuffered Tris solution $(150 \mu \mathrm{l})$ was added to each well. Plates were agitated for $5 \mathrm{~min}$ on a gyratory shaker. Then the OD was read on a microplate reader at a wavelength of $570 \mathrm{~nm}$.

\section{References}

1) Sun H. D., Xu Y. L., Jiang B., "Diterpenoids from Isodon Species," Sciences Press, Beijing, 2001, p. 5.

2) “The Pharmacopoeia of People's Republic of China," People's Health Press, Beijing, 1977, p. 186.

3) Sun H. D., Xu Y. L., Jiang B., "Diterpenoids from Isodon Species," Sciences Press, Beijing, 2001, p. 122.

4) Qin C. Q., Liu C. J., Li J. C., An X. Z., Sun H. D., Lin Z. W., Acta Bot. Yunnanica, 6, 333-334 (1984)

5) Li J. C., Liu C. J., Sun H. D., Lin Z. W., Acta Bot. Yunnanica, 8, 9395 (1986).

6) Qin C. Q., Li F. Q., Li H. L., Sun H. D., Lin Z. W., Acta Bot. Yunnanica, 8, 99-101 (1986).

7) Li J. C., Sun H. D., Lin Z. W., Acta Bot. Yunnanica, 9, 485-486 (1987).

8) Takeda Y., Fujita T., Chen C. C., Chem. Lett., 1982, 833-836 (1982).

9) Han Q. B., Zhao Q. S., Li S. H., Peng L. Y., Sun H. D., Acta Chim. Sin. (in press).

10) Zhao Q. Z., Chao J. H., Wang H. Q., Sun H. D., Zhongcaoyao, 15 , 49-50 (1984).

11) Chen Y. Z., Wu Z. W., Cheng P. Y., Acta Chim. Sin., 42, 645-649 (1984).

12) Takeda Y., Fujita T., Sun H. D., Minami Y., Ochi M., Chen C. C., Chem. Pharm. Bull., 38, 1877-1880 (1990).

13) Takeda Y., Takeda K., Fujita T., Sun H. D., Minami Y., Chem. Pharm. Bull., 38, 439-442 (1990).

14) Fujita E., Fujita T., Katayama H., Shibuya M., Shingu T., J. Chem. Soc. (C), 1970, 1674-1681 (1970).

15) Fujita E., Taoka M., Shibuya M., Fujita T., Shingu T., J. Chem. Soc., Perkin Trans. I, 1973, 2277-2281 (1973).

16) Li J. C., Liu C. J., An X. Z., Wang M. T., Zhao T. Z., Yu S. Z., Zhao G. S., Chen R. F., Acta Pharm. Sin., 17, 682-684 (1982).

17) Wang X. R., Wang H. P., Hu H. P., Sun H. D., Wang S. Q., Ueda S., Kuroda Y., Fujita T., Phytochemistry, 38, 921-924 (1995).

18) Kubo I., Kamikawa T., Kubota T., Tetrahedron, 30, 615-618 (1974).

19) Li J. C., Yuan B. M., Shen X. Y., Lin Z. W., Sun H. D., Acta Bot. Yunnanica, 15, 291-294 (1993)

20) Mosmann T., J. Immunol. Methods, 65, 55-63 (1983). 